\title{
PHYSICO-CHEMICAL, ANTIOXIDANT AND ANTIMICROBIAL PROPERTIES OF THREE DIFFERENT TYPES OF HONEY FROM CENTRAL SERBIA
}

\author{
Nikola Z. Srećković*, Vladimir B. Mihailović, Jelena S. Katanić Stanković \\ Department of Chemistry, Faculty of Science, University of Kragujevac, \\ Radoja Domanovića 12, 34000 Kragujevac, Serbia \\ *Corresponding author; E-mail: nikola.sreckovic@ pmf.kg.ac.rs \\ (Received April 9th, 2019; Accepted May 25th, 2019)
}

\begin{abstract}
There are many studies dealing with the comparison of the quality and biological characteristics of honey of distinct geographical and botanical origins. However, there is scarce literary data on the physico-chemical and biological properties of different types of honey from the same production regions. Honey samples used in this study were from the following botanical origins: forest honey (honeydew), polyfloral honey and monofloral acacia honey. All samples were provided by a local beekeeper from Sumadija district (Central Serbia) and produced during the flowering season in 2018. Spectrophotometric determination of phenolic compounds in honey samples showed that the forest honey contained the highest total phenolics $(806.10 \mathrm{mg} \mathrm{GAE} / \mathrm{kg}$ ) and flavonoids $(146.27 \mathrm{mg}$ QU/kg) contents, more than ten times higher than acacia honey (68.48 mg GAE/kg and $18.59 \mathrm{mg}$ QU/kg, respectively). Antioxidant activity was determined by $\mathrm{DPPH}^{-}$and $\mathrm{ABTS}^{+}$assays. Forest honey showed better antioxidant activity than the other examined honey samples (594.77 mg Trolox/kg for ABTS assay and $260.77 \mathrm{mg}$ Trolox/kg for DPPH assay). The minimal inhibitory concentrations (MICs) of honey samples against a panel of eleven bacterial and eight fungal species, along with yeast Candida albicans, showed that forest honey was the most effective in inhibition of their growth. These results suggest that forest honey has the best potential, among studied honey samples, for use in the human diet as food with valuable biological properties.
\end{abstract}

Keywords: honey, antioxidant, antimicrobial, phenolics, physico-chemical properties.

\section{INTRODUCTION}

Honey is a sweet, viscous food substance produced by honey bees (Apis mellifera L.). Bees produce honey from the floral nectar through regurgitation, enzymatic activity, water evaporation and store it in wax structures called honeycombs (CRANE, 1990). The main components of the honey are carbohydrates, mainly fructose (about 38\%) and glucose (about $32 \%$ ), with remaining sugars including maltose, sucrose, and other complex carbohydrates. In addition to carbohydrates, honey also contains a small but significant amount of biologically active phenolic compounds, minerals, vitamins, amino acids, proteins, enzymes, organic acids and other phytochemicals (WhITE, 1979; BUENO-COSTA et al., 2016). From ancient times up 
to present day honey has been recognized for its high nutritional and medicinal value. The therapeutic potential of honey on human health, such as neuroprotective, cardioprotective, antioxidant, antimicrobial, antidiabetic, anti-inflammatory and antiviral activity, is wellknown (ABDUlMAJEED et al., 2016; KHALIL et al., 2015; FERREIRA et al., 2009; GOMES et al., 2010; BoBIŞ et al., 2018; VAN DEN BERG et al., 2008; WATANABE et al., 2014). It is considered that honey demonstrates these activities due to its antioxidant capacity. The honey contains various antioxidants including enzymatic: catalase, glucose oxidase, peroxidase and non-enzymatic: ascorbic acid, $\alpha$-tocopherol, carotenoids, amino acid, proteins, organic acid and polyphenolic compounds (flavonoids, flavonols, catechins, cinnamic acid derivatives and other) (GHELDOF et al., 2002; FERRERES et al., 1994). Because of their complex composition, even honey of the same botanical origin can exhibit different biological activities (LONGMONT, 1991). Results from several studies showed that honey types light in color (acacia) exhibited lower values for total phenolic content and antioxidant activity than darker honey types (forest, chestnut, spruce or fir) (BERTONCELJ et al., 2007).

Frequent and uncontrolled use of pesticide and herbicide in agriculture as well as heavy international traffic caused a significant increase in the environmental pollution by pesticides and heavy metals. These impurities can also be transferred to the honey as a result of contamination during honey production, from soil, contaminated plants from which bees collect pollen, or from water consumed by bees. Recent studies showed that the concentrations of organochloric pesticides in different types of honey from the Pannonian region of Serbia, were below the maximum allowed value prescribed in Republic of Serbia (KARTAlović et al., 2015a, b). SPIRIĆ et al. (2019) showed that Serbian honey samples (linden, multifloral, honeydew and acacia) possessed good quality according to its safety criteria concerning the concentrations of $\mathrm{Cd}, \mathrm{Hg}, \mathrm{Pb}$ and $\mathrm{As}$. Another study also showed that in all analyzed honey samples, originated from different regions of Serbia, determined $\mathrm{Zn}, \mathrm{Pb}$ and $\mathrm{Cu}$ contents were in the range permitted by Serbian regulations, while $\mathrm{Cd}$ content was below limit of detection in all analyzed samples (ŠvARC-GAJIĆ and STOJANOVIĆ, 2014). According to LAZAREVIĆ (2016), the polyfloral honey from central Serbia is characterized by a lower content of metals, except the content of $\mathrm{Mn}$ and $\mathrm{Ni}$, compared to the honey from other regions of Serbia. These results suggest that the Republic of Serbia is still rich in healthy and unpolluted areas for honey production.

Considering many benefits of honey on human health, the aim of this study was to determine and compare physico-chemical properties (color, $\mathrm{pH}$ and free acidity, moisture, electrical conductivity, and hydroxymethylfurfural content (HMF)), the phenolic content, and antioxidant and antimicrobial activities of the three different samples of honey from Central Serbia.

\section{MATERIALS AND METHODS}

\section{Chemicals and instruments}

All chemicals and reagents used for the analyses were of analytical grade. Reagents used for analysis of total phenolic compounds and antioxidant assays were purchased from Sigma-Aldrich (Deisenhofen, Germany). Broths for the antimicrobial activity tests were purchased from Torlak Institute of Virology, Vaccines and Sera (Belgrade, Serbia). All physico-chemical methods were performed according to the Harmonized Methods of the International Honey Commission (BogDANOV, 2009). The Abbe-type refractometer (Carl Zeiss, Jena, Germany) was used for determining moisture content while Crison $\mathrm{pH}$-meter BASIC 20+ (Crison Instruments, Barcelona, Spain) was used for $\mathrm{pH}$ and electrical conductivity measurements. The specific rotation was determined using a Carl Zeiss 
polarimeter (Jena, Germany). The spectrophotometric measurements were performed on UVVis double beam spectrophotometer Halo DB-20S (Dynamica GmbH, Switzerland).

\section{Samples}

Honey samples used in this study were from the following botanical origins: forest (honeydew), polyfloral and monofloral acacia honey. All samples were provided by a local beekeeper from Veliko Krčmare village $\left(44^{\circ} 09^{\prime} 07.5^{\prime \prime} \mathrm{N} 20^{\circ} 55^{\prime} 11.5^{\prime \prime E}\right)$, Šumadija district, Serbia (Fig. 1) and collected during the flowering season in 2018. Before the analysis, the honey samples were stored in the glass jars, at $25^{\circ} \mathrm{C}$ in the dark place.
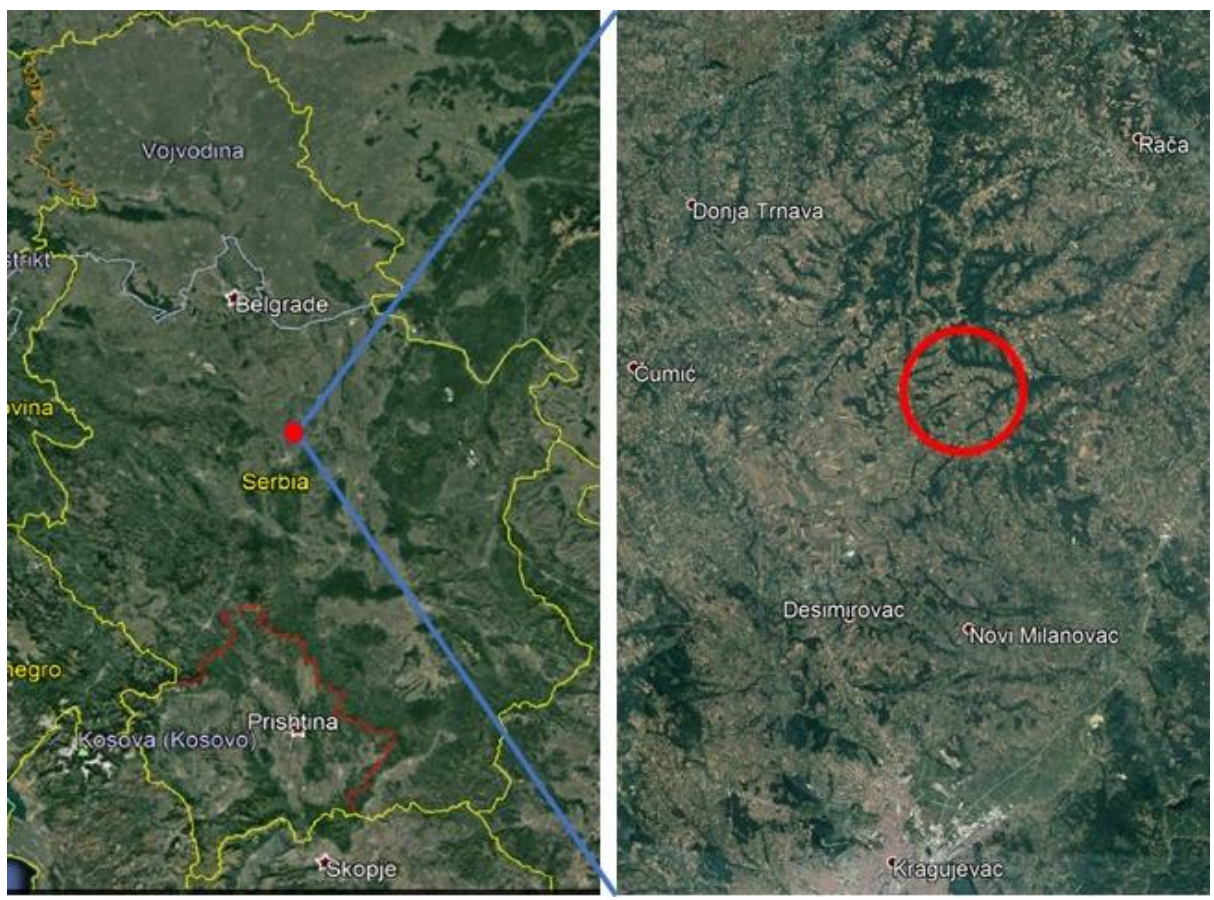

Figure 1. Geographical origin of honey samples.

\section{Color analysis}

The honey samples were dissolved in water $(1: 1 ; \mathrm{w} / \mathrm{v})$ and the color was determined by spectrophotometric measurement of the absorbance of honey solution at $635 \mathrm{~nm}$. The honey was classified based on color using Pfund scale after conversion of the absorbance values: $\mathrm{mm}$ Pfund $=-38.70+371.39 \times$ Abs (WHITE, 1984).

\section{Determination of physico-chemical parameters}

The moisture, $\mathrm{pH}$ and free acidity, electrical conductivity, specific rotation of honey samples and HMF content were determined according to the Harmonized Methods of the International Honey Commission (2009). All measurements were performed in triplicate.

\section{Determination of moisture by the refractometric method}

The method is based on the principle that the refractive index increases with solids content. Abbe refractometer was used to determine moisture in honey samples. The refractometer was thermostated at $20^{\circ} \mathrm{C}$ and calibrated with distilled water. Thereafter, homogenized honey samples were applied evenly onto the surface of the prism and the refractive index was read after $2 \mathrm{~min}$. The moisture content was determined in three 
replications and each measurement was repeated twice. The average value was used for reading moisture content from the table with standard data.

\section{pH and free acidity}

$10 \mathrm{~g}$ of honey sample was dissolved in $75 \mathrm{~mL}$ of distilled water in a $250 \mathrm{~mL}$ beaker. The solution was mixed using a magnetic stirrer and $\mathrm{pH}$ was recorded. Then, the solution was titred with $0.1 \mathrm{M} \mathrm{NaOH}$ to $\mathrm{pH} 8.3$ (the titration should be completed in $2 \mathrm{~min}$ ). The apparent volume was read, and free acidity was calculated by the following equation:

Free acidity $(\mathrm{mM}$ acid $/ \mathrm{kg}$ honey $)=\mathrm{mL}$ of $0.1 \mathrm{M} \mathrm{NaOH} \times 10$.

\section{Determination of electrical conductivity}

The electrical conductivity of the solutions obtained by dissolving $10 \mathrm{~g}$ honey in 50 $\mathrm{mL}$ distilled water was measured using an electrical conductivity cell. The determination of the electrical conductivity is based on the measurement of the electrical resistance. The electrical conductance of this solution was recorded in $\mu \mathrm{S}$. Crison $\mathrm{pH}$-meter BASIC 20+ (Crison Instruments, Barcelona, Spain) was used for the determination of electrical conductivity on working temperature of $23.3^{\circ} \mathrm{C}$.

\section{Determination of specific rotation}

$10 \mathrm{~g}$ of honey sample was dissolved in a low volume of distilled water, $10 \mathrm{~mL}$ of Carrez I solution $\left(10.6 \mathrm{~g}\right.$ of $\left.\mathrm{K}_{4} \mathrm{Fe}(\mathrm{CN})_{6} \times 3 \mathrm{H}_{2} \mathrm{O}\right)$ dissolved in $100 \mathrm{~mL}$ of distilled water) was added and mixed for $30 \mathrm{~s}$. Then, $10 \mathrm{~mL}$ of the Carrez II solution $\left(24 \mathrm{~g} \mathrm{Zn}\left(\mathrm{CH}_{3} \mathrm{COO}\right)_{2} \times 2 \mathrm{H}_{2} \mathrm{O}\right.$, and $3 \mathrm{~g}$ of glacial acetic acid in $100 \mathrm{~mL}$ of distilled water) was added and mixed again for 30 s. The mixture was made up to volume in a $100 \mathrm{~mL}$ volumetric flask with distilled water. After $24 \mathrm{~h}$, the solution was filtered, and specific angular rotation was read at $20^{\circ} \mathrm{C}$.

\section{Hydroxymethylfurfural (HMF)}

For the determination of HMF content in honey simples, $5 \mathrm{~g}$ of honey was dissolved in distilled water, quantitatively transferred into a $50 \mathrm{~mL}$ volumetric flask, $0.5 \mathrm{~mL}$ of Carrez solution I $\left(15 \mathrm{~g} \mathrm{~K}_{4}\left[\mathrm{Fe}(\mathrm{CN})_{6}\right] \times 3 \mathrm{H}_{2} \mathrm{O}\right.$ in $100 \mathrm{~mL}$ water) and $0.5 \mathrm{~mL}$ Carrez solution II $(30 \mathrm{~g}$ $\mathrm{Zn}\left(\mathrm{CH}_{3} \mathrm{COO}\right)_{2} \times 2 \mathrm{H}_{2} \mathrm{O}$ in $100 \mathrm{~mL}$ water) were added. This solution was mixed, filled with water to the mark and then filtered. First $10 \mathrm{~mL}$ of filtrate was rejected. $5 \mathrm{~mL}$ of the filtrate was transferred into two test tubes; $5 \mathrm{~mL}$ of water was added in one of the test tubes and $5 \mathrm{~mL}$ $\mathrm{Na}_{2} \mathrm{~S}_{2} \mathrm{O}_{5}\left(0.2 \mathrm{~g} \mathrm{Na}_{2} \mathrm{~S}_{2} \mathrm{O}_{5}\right.$ in $100 \mathrm{~mL}$ water) to the second test tube (reference solution) and mixed well. The absorbance of the sample solution against the reference solution was measured at 284 and $336 \mathrm{~nm}$ in $1 \mathrm{~cm}$ quartz cells. The results were expressed in $\mathrm{mg} \mathrm{HMF} / \mathrm{kg}$ of honey using following equation:

$$
\mathrm{HMF} \text { in } \mathrm{mg} / \mathrm{kg}=\left(\mathrm{A}_{284}-\mathrm{A}_{336}\right) \times 149.7 \times 5
$$

Where: $A_{284}$ is absorbance at $284 \mathrm{~nm}, \mathrm{~A}_{336}$ is absorbance at $336 \mathrm{~nm}, 149.7$ is constant, and 5 is sample weight.

\section{Total phenolics content (TPC)}

The method is based on the colored reaction of phenolics with Folin-Ciocalteu reagent (SINGLETON et al., 1999). An aqueous solution of honey $(1 \mathrm{~g} / \mathrm{mL}$ for acacia and polyfloral honey and $0.2 \mathrm{~g} / \mathrm{mL}$ for forest honey) was previously homogenized and filtered through quantitative filter paper. $0.25 \mathrm{~mL}$ of honey solution was mixed with $1.25 \mathrm{~mL}$ Folin-Ciocalteu reagent (previously diluted ten-fold with water) and $1 \mathrm{~mL}$ of $7.5 \% \mathrm{NaHCO}_{3}$. The reaction mixture was incubated for $15 \mathrm{~min}$ at $45^{\circ} \mathrm{C}$ and absorbance was read at $765 \mathrm{~nm}$. The content of 
total phenolic compounds was expressed as gallic acid equivalents (mg GAE/g honey) using a standard curve of gallic acid.

\section{Total content of flavonoids (TFC)}

An aqueous solution of honey $(1 \mathrm{~g} / \mathrm{mL}$ for acacia and polyfloral honey and $0.2 \mathrm{~g} / \mathrm{mL}$ for forest honey) was previously homogenized and filtered through quantitative filter paper. $1 \mathrm{~mL}$ of honey solution was mixed with $1 \mathrm{~mL}$ of $2 \% \mathrm{AlCl}_{3}$ solution (in methanol). The absorbance was measured at $415 \mathrm{~nm}$ after $1 \mathrm{~h}$ of incubation at room temperature (BRIGHENTE et al., 2007). The results were calculated as quercetin equivalents (mg QUE/g honey) using a calibration curve of quercetin as a standard.

\section{ABTS radical-cation scavenging activity}

For the determination of the antioxidant activity of honey samples against ABTS radical cation (2,2'-azino-bis (3-ethylbenzothiazoline-6-sulphonic acid)) the method described by RE et al. (1999) was used. In $0.2 \mathrm{~mL}$ of serial dilutions of honey samples $(1 \mathrm{~g} / \mathrm{mL}$ for acacia and polyfloral honey and $0.05 \mathrm{~g} / \mathrm{mL}$ for forest honey) was added $1.8 \mathrm{~mL}$ of ABTS solution. The absorbance was measured at $734 \mathrm{~nm}$ after $30 \mathrm{~min}$ of incubation at room temperature in a dark place. A calibration curve was prepared using Trolox as a reference standard and the results of $\mathrm{ABTS}^{+}$scavenging activity were expressed in Trolox equivalents (mg Trolox/kg honey).

\section{DPPH radical scavenging activity}

The ability of honey to neutralize the DPPH radical was estimated according to Kumarasamy et al. (2007). $1 \mathrm{~mL}$ of aqueous honey solution $(1 \mathrm{~g} / \mathrm{mL}$ for acacia and polyfloral and $0.05 \mathrm{~g} / \mathrm{mL}$ for forest honey) was mixed with $1 \mathrm{~mL}$ of DPPH solution in methanol (80 $\mu \mathrm{g} / \mathrm{mL}$ ). The mixture was left to stand for $30 \mathrm{~min}$ in the dark and absorbance was read spectrophotometrically at $517 \mathrm{~nm}$. The results were expressed as $\mathrm{mg}$ Trolox/kg honey.

\section{Antimicrobial activity}

\section{Microorganisms}

The ATCC strains were provided from the Institute of Public Health, Kragujevac, Serbia. All fungal strains were obtained from Laboratory for Microbiology, Department of Biology and Ecology, Faculty of Science, University of Kragujevac, Kragujevac, Serbia. Eleven ATTC bacterial strains were used in this study, of which five were Gram-negative, Escherichia coli (ATCC 25922), Klebsiella pneumoniae (ATCC 70063), Pseudomonas aeruginosa (ATCC 10145), Salmonella enteritidis (ATCC 13076), and Salmonella typhimurium (ATCC 14028), while six were Gram-positive, Micrococcus lysodeikticus (ATCC 4698), Enterococcus faecalis (ATCC 29212), Bacillus cereus (ATCC 10876), Bacillus subtilis (ATCC 6633), Staphylococcus epidermidis (ATCC 12228), and Staphylococcus aureus (ATCC 25923). Moreover, eight fungal isolates were used for the evaluation of antifungal activity, Trichoderma harzianum (FSB 12), Trichoderma longibrachiatum (FSB 13), Penicillium cyclopium (FSB 23), Penicillium canescens (FSB 24), Aspergillus brasiliensis (ATCC 16404), Fusarium oxysporum (FSB 91), Alternaria alternata (FSB 51), Doratomyces stemonitis (FSB 41) and yeast Candida albicans (ATCC 10259).

\section{Test assays for antimicrobial activity}

The values of minimal inhibitory concentration (MIC) of honey samples against tested microorganisms were determined according to the microdilution method (SARKER et al., 
2007). The MIC value was considered to be the lowest concentration of the tested sample capable to inhibit the growth of the microorganisms, after $24 \mathrm{~h}$. Bacterial strains were cultured for $24 \mathrm{~h}$ at $37^{\circ} \mathrm{C}$ on nutrient agar (NA), C. albicans was cultured on Sabouraud dextrose agar (SDB) for $24 \mathrm{~h}$ at $35^{\circ} \mathrm{C}$, whereas fungi were grown on potato glucose agar (PDA) for $48 \mathrm{~h}$ at $28^{\circ} \mathrm{C}$. Overnight-cultured bacterial strains were suspended in sterile normal saline and diluted to obtain an inoculum concentration of $5 \times 10^{6} \mathrm{CFU} / \mathrm{mL}$ (CLSI, 2012). The MIC determination assay was performed by a serial dilution technique with sterilized 96-well microtiter plates, whereby for bacteria strains and C. albicans was used a Mueller-Hinton broth (MHB). $80 \mu \mathrm{L}$ of two-fold serial diluted honey samples $(100 \mathrm{mg} / \mathrm{mL})$ and reference antibiotics (Erythromycin, $20 \mu \mathrm{g} / \mathrm{mL}$ ) and (Ciprofloxacin, $20 \mu \mathrm{g} / \mathrm{mL}$ ) in Muller-Hinton broth (MHB) was added to each well, followed by addition of $10 \mu \mathrm{L}$ of resazurin (indicator) and $10 \mu \mathrm{L}$ of bacterial cells suspension. The final concentration of bacteria in each well was $5 \times 10^{5}$ $\mathrm{CFU} / \mathrm{mL}$. The microplates were incubated for $24 \mathrm{~h}$ at $37^{\circ} \mathrm{C}$. The lowest concentration of the honey samples containing blue-purple indicator's color was considered as MIC.

Fungal cultures were suspended in a small amount of 5\% DMSO and diluted to obtain an inoculum concentration of $5 \times 10^{4} \mathrm{CFU} / \mathrm{mL}$ (CLSI, 2008). The concentration of the honey samples was $100 \mathrm{mg} / \mathrm{mL}$ and the applied concentration of antimycotics, nystatin and clotrimazole, was $20 \mu \mathrm{g} / \mathrm{mL}$. MICs for fungal species were also determined in sterile 96 well microtiter plates in the same way as in testing antibacterial activity, only without the addition of indicator. Microplates were incubated at $28^{\circ} \mathrm{C}$ for $48 \mathrm{~h}$. MICs were determined as the lowest concentration of extracts without visible fungal growth.

\section{Statistical analysis}

All tests were carried out in triplicate and the results were expressed as mean values \pm standard deviation (SD). Correlations among the analyzed parameters were achieved by Pearson correlation coefficients ( $r$ ) and determined using Microsoft Office Excel 365 software. The statistical comparison was performed by a one-way analysis of variance (ANOVA) followed by Fisher LSD honestly significant difference post hoc test with $p<0.05$ for all comparisons, using Origin Pro 8 statistics software package (OriginLab, Northampton, Massachusetts, USA) for Windows.

\section{RESULTS AND DISCUSSION}

\section{Physico-chemical parameters}

In the first phase of this research, five physico-chemical parameters (color, moisture content, $\mathrm{pH}$ and free acidity, electrical conductivity and specific rotation) were determined.

Table 1. Pfund scale values and color of three honey samples

\begin{tabular}{ccl}
\hline Honey samples & $\begin{array}{c}\text { Pfund scale } \\
(\mathrm{mm})\end{array}$ & Color \\
\hline Acacia honey & $-4.30 \pm 3.70$ & Water white \\
Polyfloral honey & $10.04 \pm 1.44$ & Extra white \\
Forest honey & $116.07 \pm 8.75$ & Dark amber \\
\hline
\end{tabular}

\section{Color}

Based on a Pfund scale, honey can be classified as water white, extra white, white, extra light amber, light amber, amber and dark amber (PoNTIS et al., 2014). According to the obtained results for analyzed honey samples, an obvious difference in their color intensity was 
observed. The acacia honey had water white, polyfloral honey had extra white and forest honey had dark amber color (Tab. 1). Compared to Hungarian acacia honeys, which showed higher Pfund values $(12 \pm 5 \mathrm{~mm})$ and classified as extra white honey CzIPA et al. (2019), in this research acacia honey was lighter $(-4.30 \pm 3.70 \mathrm{~mm}$ Pfund scale). Honeydew from Spain had $87 \pm 1 \mathrm{~mm}$ (Pfund scale) reported by JUAN-BORRÁs et al. (2016), which is a lower value in comparison with our result obtained for forest honey $116.07 \pm 8.75 \mathrm{~mm}$. In Serbia exists quite diverse vegetation that flourishes periodically. That allows beekeepers to collect various types of monofloral or polyfloral honeys which differ in color. Previous studies have suggested that transitional metals, which can be found in honey, react with organic compounds in honey forming a highly colorful complex (HARRIS, 2014). Also, some studies confirmed that the lighter honeys have a mild taste, while the dark honey is strong and has a slightly bitter taste (PITA-CALVO and VÁzQUEZ, 2017). According to the numerous studies, there is a clear correlation between honey color, total phenolic compounds, antioxidant and antibacterial activity (ESTEVINHO et. al., 2008; FERREIRA et al., 2009; PONTIS et al., 2014). High, positive correlations were found between the color and all analyzed characteristics of the investigated honey samples, except moisture content (Tab. 4). These results suggest that, in these samples, the more intense (dark) honey color may indicate higher biological values, antioxidant activity and phenolic contents.

\section{Moisture content}

The moisture content in all honey samples was below 20\%, which is in accordance with the standard prescribed by the European Union's Council Directive 2001/110/EC. All examined honey samples showed similar moisture contents. The acacia honey contained the lowest moisture (17.8\%), while the highest moisture was observed in polyfloral honey $18.8 \%$ (Tab. 2). The higher content of the moisture in the honey can be noticed when the honeys are harvested early in the season. This may occur when the honey has not ripened enough, or the bees did not cap off the comb. Low moisture content in honey can have a protective effect against microbials, especially during long term storage, while higher water content might cause honey fermentation and formation of acetic acid (CHIRIFIE et al., 2006). No significant correlation was found between the moisture content and other analyzed properties of the tested honey samples (Tab. 4).

Table 2. Physicochemical parameters of honey samples

\begin{tabular}{|c|c|c|c|c|c|}
\hline $\begin{array}{c}\text { Honey } \\
\text { samples }\end{array}$ & $\begin{array}{c}\text { pH and free } \\
\text { acidity }(\mathrm{mM} / \mathrm{kg})\end{array}$ & $\begin{array}{c}\text { Moisture } \\
\text { content } \\
(\mathrm{g} / 100 \mathrm{~g})\end{array}$ & $\begin{array}{c}\text { Electrical } \\
\text { conductivity } \\
(\mu \mathrm{S} / \mathrm{cm})\end{array}$ & $\begin{array}{l}\text { Specific } \\
\text { rotation }\end{array}$ & $\begin{array}{c}\text { HMF } \\
(\mathrm{mg} / \mathrm{kg})\end{array}$ \\
\hline $\begin{array}{c}\text { Acacia } \\
\text { honey }\end{array}$ & $\begin{array}{l}4.52 \pm 0.02 \\
11.17 \pm 0.76\end{array}$ & $17.8 \pm 0.2$ & $154.7 \pm 0.23$ & $-28.35 \pm 1.2$ & $11.60 \pm 1.26$ \\
\hline $\begin{array}{c}\text { Polyfloral } \\
\text { honey }\end{array}$ & $\begin{array}{l}4.57 \pm 0.02 \\
14.33 \pm 0.29\end{array}$ & $18.7 \pm 0.08$ & $211 \pm 0.58$ & $-1.47 \pm 0.6$ & $58.61 \pm 4.13$ \\
\hline $\begin{array}{c}\text { Forest } \\
\text { honey }\end{array}$ & $\begin{array}{c}5.07 \pm 0.04 \\
35.09 \pm 0.52\end{array}$ & $18.2 \pm 0.1$ & $1071 \pm 3.65$ & $+28.0 \pm 0.9$ & $1.27 \pm 0.07$ \\
\hline
\end{tabular}

\section{pH and free acidity}

Honey contains many kinds of acids, such as aromatic, aliphatic and amino acids. However, the content of different types of acids and their quantity depends very much on the type of honey. The most prevalent acid in honey is gluconic acid formed by the action of the glucose oxidase enzyme (SCHEPARTS et al., 1964). The analyzed honey samples were slightly acidic and had approximately similar $\mathrm{pH}$ values (Tab. 2). However, the forest honey had higher $\mathrm{pH}$ values (5.07) than acacia and polyfloral honey samples $(\mathrm{pH} 4.52$ and 4.57, 
respectively). Although obtained results showed a positive correlation between free acidity and $\mathrm{pH}(\mathrm{r}=0.995)$, it should be noted that the $\mathrm{pH}$ value of the honey is not directly related to free acidity due to the buffer properties of phosphate, carbonate and other mineral salts which are naturally present in honey (LAZAREVIĆ, 2016). SAKAČ et al. (2019) reported lower free acidity of acacia honey from Serbia $(9.77 \mathrm{meq} / \mathrm{kg}$ ) compared by meadow and sunflower honeys $(19.3 ; 19.1 \mathrm{meq} / \mathrm{kg}$, respectively). Similar results for acacia honey acidity were published by LAZAREVIĆ et al. (2012).

\section{Electrical conductivity}

The great differences in electrical conductivity were found in studied honey samples. Forest honey had many times higher EC values $(1071 \mu \mathrm{S} / \mathrm{cm})$ than acacia and polyfloral honeys (154.7 and $211 \mu \mathrm{S} / \mathrm{cm}$, respectively) (Tab. 2). The obtained results of electrical conductivity coincide with Serbian official Regulation on honey quality, which requires electrical conductivity values below $0.8 \mathrm{mS} / \mathrm{cm}$ for acacia and polyfloral honeys and above $0.8 \mathrm{mS} / \mathrm{cm}$ for forest honey. Acacia honey had the lowest values for electrical conductivity which coincides with results of LAZAREVIĆ et al. (2012). The electrical conductivity of polyfloral honey was in agreement with the values reported by LAZAREVIĆ et al. (2013). The value of electrical conductivity for forest honey coincides with the samples from Croatia (VASIĆ et al., 2019). The electrical conductivity of honey can be a good indicator to routine determination the botanical origin of honey (ACQUARONE et al., 2007). The conductivity of honey depends on its ash (minerals) and acid contents, where a higher ash and acid contents show the higher conductivity (ADENEKAN et al., 2010). Based on the high electrical conductivity of the forest honey, it can be concluded that the it was quite rich in minerals. A significant correlation was also found between electrical conductivity and most of the other parameters. However, there was a negative correlation between electrical conductivity and moisture content $(\mathrm{r}=-0.00922)$.

\section{Determination of specific rotation}

The specific rotation of honey is the result of the rotation of linearly polarized light by carbohydrates. For example, most of honeydew honeys (forest honey) are usually righthanded due to the high content of di- and oligosaccharides that have a positive specific rotation, especially maltose, melezitose, erlose, and raffinose. Forest honey has lower fructose content and contains trisaccharides such as melezitose or erlose which, together with glucose, generally give a positive net specific rotation (PITA-CALVO and VÁZQUEZ, 2017). On the other hand, natural nectar honey contains a high concentration of fructose resulting in a negative specific rotation value (KOWALSKI et al., 2013). The measured specific rotations of acacia, polyfloral and forest honey were in range of -28.35 to +28 (Tab. 2). The obtained results indicate a high concentration of fructose in acacia honey and confirm the presence of dextrorotatory sugars which together with glucose, give a positive net specific rotation. The specific rotation of acacia and forest honey from Slovenia $(-19.6 \pm 6.6 ; 12.0 \pm 9.8$, respectively) (BERTONCELJ et al., 2011) was similar to our results. Pearson correlation coefficients (Tab. 4) showed a high correlation between the specific rotation of honey samples and TFC, free acidity and electrical conductivity, suggesting that honey with positive specific rotation (forest honey) may contain higher values of flavonoids, free acids and mineral contents (higher electrical conductivity).

\section{Hydroxymethylfurfural (HMF)}

Hydroxymethylfurfural (HMF) is a cyclic aldehyde formed in the honey by the dehydration of fructose and glucose in the acidic medium. With the rise in temperature, the rate of this reaction also increases (KOWALSKI et al., 2013). The permitted content of HMF in 
honey, according to the Serbian rulebook (Pravilnik o kvalitetu med i drugih pčelinjih proizvoda, Službeni glasnik RS No. 101/15) is $40 \mathrm{mg} / \mathrm{kg}$, and the same allowed content is prescribed by the Codex Standard and European Regulations (Codex Alimentarius Commission, 2001, Council Directive 2001/110/EC). Based on the presented results, HMF content in acacia $(11.60 \mathrm{mg} / \mathrm{kg})$ and forest honeys $(1.27 \mathrm{mg} / \mathrm{kg})$ is in accordance with the mentioned standards. In polyfloral honey a higher content of HMF $(58.61 \mathrm{mg} / \mathrm{kg})$ was found and this significant increase might be considered as a consequence of the overheating, inadequate storage or could be a result of adulteration by adding invert sugar syrup (RUIZEMATUTE et al., 2010). Compared to the published results for forest honey collected from different parts of Serbia during the 2017 harvest season (SPIRIĆ et al., 2019), HMF content of the forest honey obtained in our study was lower. HMF content in acacia honey from our study was similar to the previous published results for acacia honey samples from different Serbian regions (LAZAREVIĆ, 2016).

\section{Total phenolic and flavonoid contents}

The content of total phenolic compounds (TPC) in honey depends on the geographical and botanical origin of honey. The obtained results for three tested honey samples showed that total phenolics content of forest honey $(806.10 \mathrm{mg}$ GAE $/ \mathrm{kg}$ honey) was significantly higher $(p<0.05)$ in comparison with acacia and polyfloral samples $(68.48$ and $87.46 \mathrm{mg}$ GAE/kg honey, respectively) (Tab. 3). Based on the results of total flavonoids content it can be concluded that dark honey contained the highest concentration $(p<0.05)$ of flavonoids (146.27 mg QUE/kg honey) compared with other tested samples. Analysis of three types of monofloral honeys from Portugal showed that dark honey was richer in phenolics content (FERREIRA et al., 2009), which was also confirmed in our research. Turkish acacia and polyfloral honeys showed higher total phenolic content $(160.02$ and $295.40 \mathrm{mg} \mathrm{GAE} / \mathrm{kg}$, respectively), but lower flavonoid content (15.8 and $16.5 \mathrm{mg} \mathrm{QUE} / \mathrm{kg}$, respectively) compared to our results (CAN et al., 2015). Also, the total content of phenolic compounds in acacia and forest honeys is higher than in Croatian honeys (43.66 for acacia and $318.6 \mathrm{mg} \mathrm{GAE} / \mathrm{kg}$ honey for forest honey) (KRPAN et al., 2009; FLANJAK et al., 2016).

\section{Antioxidant activity}

Two methods were used to determine the antioxidant activity of the honey samples, ABTS $^{+}$and DPPH radical scavenging methods. The forest honey showed the highest ABTS and DPPH radical scavenging activities $(p<0.05)$, compared with antioxidant activities of acacia and polyforal honey, while there was no significant difference $(p>0.05)$ between antioxidant activities of acacia and polyforal honey (Tab. 3). The ABTS scavenging activity of tested honey samples ranged between 26.72 and $594 \mathrm{mg}$ Trolox/kg honey, while their DPPH scavenging potential was several times lower. These results are in accordance with the results reported by BUENO-COSTA et al. (2010), which confirmed that the ABTS scavenging potential of honey was much higher than antioxidant activity on DPPH radicals. PONTIS et al. (2014) demonstrated a positive relationship between phenolic concentration, antioxidant capacity and the color of monofloral and polyfloral honeys. According to Pearson correlation coefficients (Tab. 4), an extremely high correlation was observed between TPC, ABTS, and DPPH suggesting that TPC had the highest influence on the antioxidant activity of examined honey samples. 
Table 3. Total phenolic and flavonoid contents and antioxidant activity of three honey samples

\begin{tabular}{lcccc}
\hline Honey samples & $\begin{array}{c}\text { Total phenolic content } \\
\text { (mg GAE/kg honey) }\end{array}$ & $\begin{array}{c}\text { Total flavonoid content } \\
\text { (mg QUE/kg honey) }\end{array}$ & $\begin{array}{c}\text { ABTS scavenging activity } \\
\text { (mg Trolox/kg honey) }\end{array}$ & $\begin{array}{c}\text { DPPH scavenging } \\
\text { activity } \\
\text { (mg Trolox/kg honey) }\end{array}$ \\
\hline Acacia honey & $68.48 \pm 5.53^{\mathrm{a}}$ & $18.59 \pm 1.71^{\mathrm{a}}$ & $26.72 \pm 0.99^{\mathrm{a}}$ & $8.36 \pm 0.42^{\mathrm{a}}$ \\
Polyforal honey & $87.46 \pm 10.92^{\mathrm{a}}$ & $39.55 \pm 0.95^{\mathrm{b}}$ & $37.02 \pm 0.86^{\mathrm{a}}$ & $11.97 \pm 0.35^{\mathrm{a}}$ \\
Forest honey & $806.10 \pm 38.91^{\mathrm{b}}$ & $146.27 \pm 1.45^{\mathrm{c}}$ & $594.77 \pm 38.30^{\mathrm{b}}$ & $260.77 \pm 0.45^{\mathrm{b}}$ \\
\hline
\end{tabular}

In each column different letters mean significant differences $(p<0.05)$; GAE, gallic acid equivalents, QUE, quercetin equivalents.

Table 4. Pearson's correlation coefficients for phenolic compounds, flavonoids, antioxidant activity, physico-chemical parameters and color in honey samples

\begin{tabular}{|c|c|c|c|c|c|c|c|c|c|c|c|}
\hline & TPC & TFC & ABTS & DPPH & $\mathrm{EC}$ & pH & FA & MC & SR & HMF & Color \\
\hline ABTS & & & 1 & 0.999994 & 0.99924 & 0.999868 & 0.993717 & -0.0482 & 0.88642 & -0.6269 & 0.997264 \\
\hline EC & & & & & 1 & 0.999741 & 0.997325 & -0.00922 & 0.90380 & -0.59605 & 0.999388 \\
\hline pH & & & & & & 1 & 0.995401 & -0.03199 & 0.89382 & -0.61418 & 0.998332 \\
\hline FA & & & & & & & 1 & 0.063899 & 0.93266 & -0.53576 & 0.999272 \\
\hline MC & & & & & & & & 1 & 0.41960 & 0.80841 & 0.025767 \\
\hline HMF & & & & & & & & & & 1 & -0.56759 \\
\hline Color & & & & & & & & & & & 1 \\
\hline
\end{tabular}

Pearson's correlation between total phenolic content (TPC), total flavonoid content (TFC), antioxidant activity (ABTS and DPPH), electrical conductivity (EC), $\mathrm{pH}$, free acidity (FA), moisture content (MC), specific rotation (SR), hydroxymethylfurfural (HMF) and color. 


\section{Antimicrobial activity}

The results of antibacterial and antifungal activities of the three honey samples evaluated by microdilution method are reported in Table 5 and Table 6 .

Table 5. Antibacterial activity of honey samples and reference antibiotics

\begin{tabular}{lccccc}
\hline \multirow{2}{*}{$\begin{array}{c}\text { Bacterial } \\
\text { strains }\end{array}$} & \multicolumn{3}{c}{ MIC values $(\mathbf{m g} / \mathbf{m L})$} & \multicolumn{2}{c}{ MIC values $(\boldsymbol{\mu g} / \mathbf{m L})$} \\
\cline { 2 - 6 } & $\begin{array}{c}\text { Acacia } \\
\text { honey }\end{array}$ & $\begin{array}{c}\text { Polyfloral } \\
\text { honey }\end{array}$ & $\begin{array}{c}\text { Forest } \\
\text { honey }\end{array}$ & Erythromycin & Ciprofloxacin \\
\hline E. coli & $>100$ & $>100$ & 100 & 10 & 2.5 \\
P. aeruginosa & $>100$ & $>100$ & 100 & 20 & 0.3125 \\
S. typhimurium & $>100$ & $>100$ & 100 & 0.625 & 10 \\
S. epidermidis & $>100$ & $>100$ & 100 & $>20$ & 5 \\
K. pneumoniae & $>100$ & $>100$ & 100 & 10 & 1.25 \\
B. subtilis & $>100$ & $>100$ & 100 & 0.625 & $>20$ \\
B. cereus & 25 & 25 & 6.25 & 0.3125 & 0.3125 \\
E. faecalis & $>100$ & $>100$ & 100 & 0.625 & 20 \\
M. lysodeikticus & $>100$ & $>100$ & $>100$ & $>20$ & 2.5 \\
S. epidermidis & 100 & $>100$ & 50 & 0.3125 & 5 \\
S. aureus & $>100$ & $>100$ & 50 & $>20$ & 5 \\
\hline
\end{tabular}

The investigated types of honey showed similar activity against most of the tested bacteria. However, the forest honey showed the highest antibacterial activity against all tested bacterial species with MIC values of $100 \mathrm{mg} / \mathrm{mL}$, except for M. lysodeikticus (MIC >100 $\mathrm{mg} / \mathrm{mL}$ ). Among all Gram-positive bacteria, B. cereus was the most sensitive strain against all honey types with MIC values ranged from 6.25 to $25 \mathrm{mg} / \mathrm{mL}$. The forest honey was more effective on Gram-positive bacteria compared to Gram-negative, especially against $B$. cereus, $S$. epidermidis, and $S$. aureus. Presented results were in accordance with the research of ALVAREZ-SUAREZ et al. (2010), which also confirmed that Gram-positive bacteria were more sensitive to the honey samples than Gram-negative ones. The current results for antibacterial activity of forest honey against $S$. aureus and $P$. aeruginosa were in accordance with results for Croatian honeydew honey, (GoBIN et al., 2018). Erythromycin and Ciprofloxacin were used as reference antibiotics, with MIC values much lower than those obtained for honey, ranging from $0.3125-20 \mu \mathrm{g} / \mathrm{mL}$.

Table 6. Antifungal activity of honey samples and reference antimycotics

\begin{tabular}{lccccc}
\hline \multirow{2}{*}{$\begin{array}{c}\text { Fungal } \\
\text { strains }\end{array}$} & \multicolumn{2}{c}{ MICs values $(\mathbf{m g} / \mathbf{m L})$} & \multicolumn{2}{c}{ MICs values $(\boldsymbol{\mu g} / \mathbf{m L})$} \\
\cline { 2 - 5 } & $\begin{array}{c}\text { Acacia } \\
\text { honey }\end{array}$ & $\begin{array}{c}\text { Polyfloral } \\
\text { honey }\end{array}$ & $\begin{array}{c}\text { Forest } \\
\text { honey }\end{array}$ & Nystatin & Clotrimazole \\
\hline F. oxysporum & $>100$ & $>100$ & $>100$ & 1.125 & 0.625 \\
A. brasiliensis & $>100$ & $>100$ & $>100$ & 1.125 & 0.625 \\
A. alternata & $>100$ & $>100$ & $>100$ & 0.625 & $<0.156$ \\
D. stemonitis & $>100$ & $>100$ & $>100$ & 1.125 & $<0.156$ \\
T. longibrachiatum & $>100$ & $>100$ & 100 & 5 & 2.5 \\
T. harzianum & $>100$ & $>100$ & 100 & 5 & 5 \\
P. canescens & $>100$ & $>100$ & 100 & 2.5 & 0.3125 \\
P. cyclopium & $>100$ & $>100$ & 100 & 2.5 & 0.3125 \\
C. albicans & $>100$ & $>100$ & $>100$ & 1.25 & $/$ \\
\hline
\end{tabular}

Most of the tested fungal strains showed resistance to the tested concentrations of honey samples. Concerning the antifungal activity (Tab. 6), the forest honey revealed certain antifungal potential against two Trichoderma spp. (T. longibrachiatum and T. harzianum) and two Penicillium spp. (P. canescens and P. cyclopium) with MIC values of $100 \mathrm{mg} / \mathrm{mL}$. MIC 
values for reference antimycotics were in the range from $0.625-2.5 \mu \mathrm{g} / \mathrm{mL}$ for Nystatin and $<0.156-0.625 \mu \mathrm{g} / \mathrm{mL}$ for Clotrimazole.

The use of honey to treat microbial infections dates to ancient times (MOLAN, 1992). The antimicrobial properties of honey are the result of a high sugar osmolarity or the presence of other biologically active compounds (LEYVA-JIMENEZA et al., 2019). The high content of various sugars in honey in combination with low moisture content can cause osmotic stress, which prevents the spoilage of honey caused by microorganisms. One of the antibacterial compounds of honey, whose presence and origin was confirmed by WHITE et al. (1963), is hydrogen peroxide $\left(\mathrm{H}_{2} \mathrm{O}_{2}\right)$. For the formation of hydrogen peroxide, a glucose oxidase enzyme was added by a bee in the collected nectar to convert glucose to gluconic acid, whereby hydrogen peroxide is produced as a side product (WHITE, et. al., 1963). However, the neutralization of hydrogen peroxide by catalase is not associated with a decrease in antibacterial activity, which means that hydrogen peroxide is not a key antimicrobial factor (ROSHAN et al., 2016). The antimicrobial activity of honey is directly related to the botanical origin of honey, since there was a great difference in their content of phenolic compounds, flavonoids and phenolic acids (MOLAN et al., 2000).

\section{CONCLUSION}

Each type of honey has a distinct taste and aroma and presented results of physicochemical analyses showed a wide variability among three analyzed honey types. Monofloral honeys are regarded as a more valuable class of honeys, often achieving higher prices than honey blends. In European countries 30 to $50 \%$ of the marketed honey is monofloral. The forest honey, because of the bitter taste, was unjustifiably found on the list of poorer quality honey with lower market value. However, physico-chemical parameters and biological activity of forest honey showed that it should not be neglected. To our knowledge, this is the first report about physico-chemical and biological characteristics of different types of honey from this locality in the central part of Serbia. The presented results also showed that forest honey possessed a significantly higher content of phenolic compounds than other two investigated honey samples. This study confirmed that forest honey had much higher antioxidant and antimicrobial activities. Based on the results, forest honey (Dark amber) has the best potential among studied honey samples for using in the human diet as food with valuable biological properties. Due to the possibility of collecting a variety of honeys throughout the year, Serbia has a high potential for the development of beekeeping. The goal of this work was to promote beekeeping in Serbia as an important agricultural discipline of national interest and the benefits of using honey (particularly forest honey) in the human diet.

\section{Acknowledgments}

The authors are grateful for the financial support provided by the Ministry of Education, Science and Technological Development of the Republic of Serbia (Grant No. III43004). The authors thank Prof. Dr. Slavko Radenković, Dr. Jelena Tošović and MSc Slađana Đorđević for the assistance with measurements of physico-chemical parameters.

\section{References:}

[1] Abdulmajeed, W.I., Sulieman, H.B., Zubayr, M.O., Imam, A., Amin, A., Biliaminu, S.A., OYewOle, L.A., OwOYele, B.V. (2016): Honey prevents neurobehavioural deficit and oxidative stress induced by lead acetate exposure in male wistar rats preliminary study. Metabolic Brain Disease 31: 37-44. doi: 10.1007/s1101 $1-015-9733-6$ 
[2] Acquarone, C., Buera, P., Elizalde, B. (2007): Pattern of pH and electrical conductivity upon honey dilution as a complementary tool for discriminating geographical origin of honeys. Food Chemistry 101(2): 695-703. doi: 10.1016/j.food chem.2006.01.058

[3] Adenekan, M.O., Amusa, N.A., Lawal, A.O., OkPeze V.E. (2010): Physicochemical and microbiological properties of honey samples obtained from Ibadan. Journal of Microbiology and Antimicrobials 2: 100-104.

[4] Alvarez-Suarez, J.M., Tulipani, S., Díaz, D., Estevez, Y., Romandini, S., Giampieri, F., Damiani, E., Astolfi, P., Bompadre, S., Battino, M. (2010): Antioxidant and antimicrobial capacity of several monofloral Cuban honeys and their correlation with color, polyphenol content and other chemical compounds. Food and Chemical Toxicology 48(8-9): 2490-2499. doi: 10.1016/j.fct.2010.06.021

[5] Bertoncelu, J., DoberŠEK, U., JAMnik, M., Golob, T. (2007): Evaluation of the phenolic content, antioxidant activity and colour of Slovenian honey. Food Chemistry 105(2): 822-828. doi: 10.1016/j.foodchem.2007.01.060

[6] BertoncelJ, J., Golob, T., Kropf, U., KorošEC, M. (2011): Characterisation of Slovenian honeys on the basis of sensory and physicochemical analysis with a chemometric approach. International Journal of Food Science and Technology 46(8): 1661-1671. doi: 10.1111/j.1365-2621.2011.02664.x

[7] Bobiş, O., DeZmirean, D.S., Moise, A.R. (2018): Honey and diabetes: The importance of natural simple sugars in diet for preventing and treating different type of diabetes. Oxidative Medicine and Cellular Longevity 2018: 1-12. doi: 10.1155/2018/ 4757893

[8] Bogdanov, S. (2009): Harmonized methods of the International Honey Commission. World Network of Honey Sciences. p. 26-35.

[9] Brighente, I.M.C., Dias, M., Verdi, L.G., Pizzolatti M.G., (2007): Antioxidant activity and total phenolic content of some Brazilian species. Pharmaceutical Biology 45(2): 156-161. doi :10.1080/13880200601113131

[10] Bueno-Costa, F.M., Zambiazi, R.C., Bohmer, B.W., Chaves, F.C., Padilha da Silva, W., ZANUSSO, J.T., DUTRA, I. (2016): Antibacterial and antioxidant activity of honeys from the state of Rio Grande do Sul, Brazil. LWT - Food Science and Technology 65: 333-340. doi: 10.1016/j.lwt.2015.08.018

[11] Can, Z., Yildiz, O., Sahin, H., Turumtay, E.A., Silici, S., Kolyli, S. (2015): An investigation of Turkish honeys: their physico-chemical properties, antioxidant capacities and phenolic profiles. Food Chemistry 180: 133-141. doi: 10.1016/j.foodchem.2015.02.024

[12] Chirifie, J., ZAmora, M.C., MotTo A. (2006): The correlation between water activity and $\%$ moisture in honey: Fundamental aspects and application to Argentine honeys. Journal of Food Engineering, 72(3): 287-292. doi: 10.1016/j.jfoodeng.2004.12.009

[13] ClSi, Clinical and Laboratory Standards Institute (2012): Methods for dilution antimicrobial susceptibility tests for bacteria that grow aerobically. Ninth ed. (Approved Standard. Document M07. CLSI), vol. M07-A9, Clinical and Laboratory Standards Institute, Wayne, PA.

[14] CLSI, CLINICAL AND LABORATORY STANDARDS INSTITUTE (2008): Reference method for broth dilution antifungal susceptibility testing of filamentous fungi. second ed. (Approved Standard. Document M38. CLSI), vol. M38-A2 Clinical and Laboratory Standards Institute, Wayne, PA.

[15] Codex Alimentarius Commission (2001): Revised Codex Standards for Honey. Codex Standard 12-1981, Rev. 2. 
[16] CRANE, E. (1990): Honey from honeybees and other insects. Ethology Ecology \& Evolution 3 (sup1): 100-105. doi: 10.1080/03949370.1991.10721919

[17] CzIPA, N., PhILliPs, C.J.C., KovÁCs B. (2019): Composition of acacia honeys following processing, storage and adulteration. Journal of Food Science and Technology 56(3): 1245-1255. doi: 10.1007/s13197-019-03587-y

[18] Directive 2014/63/EU of the European Parliament and of the Council amending Council

[19] Directive 2001/110/EC relating to honey. Official Journal of the European Communities, 2014; L164/1.

[20] Ferreira, I.C.F.R., Aires, E., BArreira, J.C.M., Estevinho, L.M. (2009): Antioxidant activity of Portuguese honey samples: Different contributions of the entire honey and phenolic extract. Food Chemistry 114(4): 1438-1443. doi: 10.1016/j.foodchem.2008.11.028

[21] Ferreres, F., Tomas-Barberan, F. A., Soler, C., Garcia-Viguera, C. (1994): A simple extractive technique for honey flavonoid HPLC analysis. Apidologie 25(1): 2130. doi: 10.1051/apido:19940103

[22] Flanjak, I., Kenjerić, D., Primorac, LJ. (2016): Characterisation of selected Croatian honey types based on the combination of antioxidant capacity, quality parameters, and chemometrics. European Food Research and Technology 242(4): 467-475. doi: 10.1007/s00217-015-2557-0

[23] Gheldof, N., Wang, X.H., ENGESETH, N.J. (2002): Identification and quantification of antioxidant components of honeys from various floral sources. Journal of Agricultural and Food Chemistry, 50(21): 5870-5877.

[24] Gobin, I., Crnković, G., Magdalenić, M., Begić, G., Babić, A., Lušić, D., VuČKOVIĆ, D. (2018): Antibacterial potential of Croatian honey against antibiotic resistant pathogenic bacteria. Medicinski Glasnik 15(2): 139-144. doi: 10.17392/95118.

[25] Gomes, S., Dias, L.G., Moreira, L.L., Rodrigues, P., Estevinho L. (2010): Physicochemical, microbiological and antimicrobial properties of commercial honeys from Portugal. Food and Chemical Toxicology 48(2): 544-548. doi: 10.1016/j.fct.2009.11.029

[26] HARRIS, E.D. (2014): Minerals in food. DEStech Publications Inc, Lancaster, PA, USA, 19-22.

[27] Juan-Borrás, M., Soto, J., Gil-Sánchez, L., Pascual-Maté, A., Escriche, I. (2016): Antioxidant activity and physico-chemical parameters for the differentiation of honey using a potentiometric electronic tongue. Journal of the Science of Food and Agriculture 97(7): 2215-2222. doi: 10.1002/jsfa.8031

[28] Kartalovic, B., Babic, J., Prica, N., Zivkov-Balos. M., Jaksic, S., Mihaljev, Z., Cirkovic, M. (2015a): The presence of lindane in different types of honey in the Pannonian region. Bulgarian Journal of Agricultural Science 21(sup1): 208-212.

[29] Kartalovic, B., Jovanic, S., Jaksic, S., Prica, N., Zivkov-Balos, M., Babic, J., CIRKOVIC, M. (2015b): Residues of organochlorine pesticides in different types of honey in the Pannonian region Republic of Serbia, Wulfenia Journal 22(2): 261-270.

[30] Khalil, M.I., Tanvir, E.M., Afroz, R., Sulaiman, S.A., Gan, S.H. (2015): Cardioprotective Effects of Tualang Honey: Amelioration of Cholesterol and Cardiac Enzymes Levels. BioMed Research International Article ID 286051, 8 pages. doi: $10.1155 / 2015 / 286051$ 
[31] Kowalski, S., Łukasiewicz, M., Berski W. (2013): Applicability of physicochemical parameters of honey for identification of the botanical origin. Acta Scientiarum Polonorum Technologia Alimentaria, 12(1): 51-59.

[32] Krpan, M., Marković, K., ŠArić, G., Skoko, B., HruŠKar, M., VAhČIĆ, N. (2009): Antioxidant Activities and Total Phenolics of Acacia Honey. Czech Journal of Food Sciences 27: 245-247.

[33] Kumarasamy, Y., Byres, M., Cox, P.J., Jaspars, M., Nahar, L., Sarker, S.D. (2007): Screening seeds of some Scottish plants for free-radical scavenging activity. Phytotherapy Research, 21(7): 615-621. doi: 10.1002/ptr.2129

[34] LAZAREVIĆ, K.B. (2016): Physico-chemical characterization and classification of honey from the territory of The Republic of Serbia according to regional and botanical origin using multivariate chemometric analysis. PhD thesis, Faculty of Chemistry, Belgrade. [in Serbian]

[35] Lazarević, K.B., Andrić, F., Trifković, J., Tešić, Ž., Milojković-Opsenica D. (2012): Characterisation of Serbian unifloral honeys according to their physicochemical parameters. Food Chemistry 132(4): 2060-2064. doi: 10.1016/j.food chem.2011.12.048

[36] Lazarević, K.B., Trifković, J.Đ., Andrić, F.LJ., TeŠIĆ, Ž.Lu., AnĐElKović, I.B., RADOVIĆ, D.I., NEDIĆ, N.M., MilOJKOVIĆ-OPSENICA, D.M. (2013): Quality parameters and pattern recognition methods as a tool in tracing the regional origin of multifloral honey. Journal of the Serbian Chemical Society 78(12): 1875-1892. doi: 10.2298/ JSC130701099L

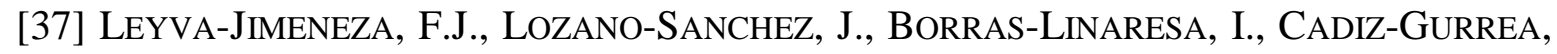
M.L., MAHMOODI-KHALEDI, E. (2019): Potential antimicrobial activity of honey phenolic compounds against Gram positive and Gram negative bacteria. LWT - Food Science and Technology, 101: 236-245. doi: 10.1016/j.lwt.2018.11.015

[38] Longmont, N.H.B. (1991): Definition of Honey and Honey Products; Ultrafiltered Honey. National Honey Board, CO. Retrieved from http://web.archive.org/web/2007 1203010606/http://www.honey.com/downloads/honeydefs.pdf

[39] Molan P.C. (1992): The antibacterial activity of honey: 1. The nature of the antibacterial activity. Bee World, 73(1): 5-28.

[40] Molan, P.C., CoOPER, R.A. (2000): Honey and sugar as a dressing for wounds and ulcers. Tropical doctor 30(4): 249-250. doi: 10.1177/004947550003000429

[41] Pita-Calvo, C., Vázquez, M. (2017): Differences between honeydew and blossom honeys: A review. Trends in Food Science \& Technology 59: 79-87. doi: 10.1016/j. tifs.2016.11.015

[42] Pontis, J.A., Alves da Costa, L.A.M., Reis da Silva, S.J., Flach A. (2014): Color, phenolic and flavonoid content, and antioxidant activity of honey from Roraima, Brazil. LWT - Food Science and Technology 34(1): 69-73. doi: 10.1590/S010120612014005000015

[43] Pravilnik o kvalitetu meda i drugih pčelinjih proizvoda, Sl. glasnik RS, No. 101/15

[44] Re, R., Pellegrini, N., Proteggente, A., Pannala, A., Yang, M., Rice Evans, C. (1999): Antioxidant activity applying an improved ABTS radical cation decolorization assay. Free Radical Biology and Medicine 26(9-10): 1231-1237.

[45] Roshan, N., RIPPERs, T., LOCHER, C., HAMmer, K.A. (2016): Antibacterial activity and chemical characteristics of several Western Australian honeys compared to manuka honey and pasture honey. Archives of Microbiology 199(2): 1-9. doi: 10.1007/ s00203-016-1308-3 
[46] Ruiz-Matute, A., Weiss, M., Sammataro, D., Finely, J., Sanz, M.L. (2010): Carbohydrate composition of high-fructose corn syrups (HFCS) used for bee feeding: effect on honey composition. Journal of Agricultural and Food Chemistry 58(12): 7317-7322. doi: 10.1021/jf100758x

[47] Sakač, M.B., Jovanov, P.T., Marić, A.Z., Pezo, L.L., Kevrešan, Ž.S., Novaković, A.R., NEDELJKOVIĆ, N.M. (2019): Physicochemical properties and mineral content of honey samples from Vojvodina (Republic of Serbia). Food Chemistry 276: 15-21. doi: 10.1016/j.foodchem.2018.09.149

[48] Sarker, S.D., NAhar, L., Kumarasamy Y. (2007): Microtitre plate-based antibacterial assay incorporating resazurin as an indicator of cell growth, and its application in the in vitro antibacterial screening of phytochemicals. Methods 42(4): 321-324.

[49] Scheparts, A.I., Subers M.H. (1964): The glucose oxidase of honey. I. Purification and some general properties of the enzyme. Biochimica et Biophysica Acta 85: 228237.

[50] Singleton, V.L., Orthofer, R., LAmuela-Raventos R.M. (1999): Analysis of total phenols and other oxidation substrates and antioxidants by means of Folin-Ciocalteu reagent oxidants and antioxidants. Method in Enzymology 299:152-178. doi: 10.10 16/S0076-6879(99)99017-1

[51] Spirić, D., Ćirić, J., ĐorĐevića, V., Nikolić, D., Janković, S., Nikolić, A., Petrović, Z., Katanić, N., Teodorović, V. (2019): Toxic and essential element concentrations in different honey types. International Journal of Environmental Analytical Chemistry 99(5): 474-485. doi: 10.1080/03067319.2019.1593972

[52] Švarc-Gajić, J., Stojanović Z. (2014): Direct Determination of Heavy Metals in Honey by Potentiometric Stripping Analysis. International Journal of Food Processing Technology 1: 1-6. doi: 10.15379/2408-9826.2014.01.02.1

[53] Van Den Berg, A.J., Vand Den Worm, E., Van Ufford, H.C., Halkes, S.B., HoekstRa, M.J., BeuKelman, C.J., (2008): An in vitro examination of the antioxidant and anti-inflammatory properties of buckwheat honey. Journal of Wound Care 17(4): 172-174, 176-178. doi: 10.12968/jowc.2008.17.4.28839

[54] Vasić, V., GaŠIĆ, U., Stanković, D., LuŠIĆ, D., VukiĆ-LuŠIĆ, D., MilojkoviĆOPSENICA, D., TEŠIĆ, Ž., TRIFKOVIĆ, J. (2019): Towards better quality criteria of European honeydew honey: Phenolic profile and antioxidant capacity. Food chemistry 274: 629-641. doi: 10.1016/j.foodchem.2018.09.045.

[55] Watanabe, K., Rahmasari, R., Matsunaga, A., Kobayashi, N. (2014): Antiinfluenzaviral effects of honey in vitro: Potent High Activity of Manuka Honey. Archives of Medicinal Research 45(5): 359-365. doi: 10.1016/j.arcmed.2014.05.006

[56] White, J.W. (1979): "Composition of Honey," In: Crane, E. (ed): Honey: A Comprehensive Survey, Heinemann: 157-206 pp.

[57] White, J.W. (1984): Instrumental color classification of honey: Collaborative study. Journal of the Association of Official Analytical Chemists 67(6): 1129-1131.

[58] White, J.W.J., Subers, M.H., SchePartz, A.I. (1963): The identification of inhibine, the antibacterial factor in honey, as hydrogen peroxide and its origin in a honey glucose oxidase system. Biochimica et Biophysica Acta (BBA) - Specialized Section on Enzymological Subjects 73(1): 57-70. doi: 10.1016/0926-6569(63)90108-1 